\title{
Residual Effect of Organics, Phosphorus Levels and Application of Fertilizer Levels on Wheat in Soybean-Wheat Cropping Sequence in Vertisols
}

\author{
M. S. Waghmare ${ }^{1 *}$, P. G. Chavan ${ }^{2}$ and P. K. Rathod ${ }^{2}$ \\ ${ }^{1}$ Department of Soil Science \& Agril. Chemistry, College of Agriculture, \\ At Post Kini, Ter Road, Osmanabad 413501 (MS) \\ ${ }^{2}$ College of Agriculture, Osmanabad, Vasantrao Naik Marathwada \\ Krishi Vidyapeeth, Parbhani (MS), India \\ *Corresponding author
}

A B S T R A C T

\section{Keywords}

Organic matter, $\mathrm{P}$ levels, Uptake,

Nutrients, Yield and quality parameters

Article Info

Accepted:

15 May 2020

Available Online:

10 June 2020
A field experiment was conducted to study the residual effect of organics, Phosphorus levels and application of fertilizer levels on wheat under soybean-wheat cropping sequence in vertisols during 2010-11 and 2011-12 at College of Agriculture, Parbhani. The experiment was laid down with in split plot design with three sources of organic matter $(0$, FYM @ 5t ha-1 + PSB and Vermicompost (VC) @ 5t ha-1 + PSB ), four levels of P $\left(0,30,60\right.$ and $\left.90 \mathrm{~kg} \mathrm{P}_{2} \mathrm{O}_{5} \mathrm{~kg} \mathrm{ha}^{-1}\right)$ and three fertilizer levels (0, 50\% RDF and $\left.100 \% \mathrm{RDF}\right)$ to wheat in soybean-wheat cropping sequence. The results on pooled basis indicated that available N,P and $\mathrm{K} \mathrm{kg} \mathrm{ha}^{-1}$ was significantly influenced due to residual effect of organics, P levels and application of fertilizer levels to wheat after soybean at 30,60 DAS and at harvest. Among the organics residual effect of VC @ $5 \mathrm{tha}^{-1}+$ PSB recorded maximum available $\mathrm{N}\left(170.29,160.82\right.$ and $\left.146.2503 \mathrm{~kg} \mathrm{ha}^{-1}\right), \mathrm{P}\left(11.16,10.43\right.$ and $\left.10.3003 \mathrm{~kg} \mathrm{ha}^{-1}\right)$ and $\mathrm{K}\left(710.13,701.18\right.$ and $\left.686.76 \mathrm{~kg} \mathrm{ha}^{-1}\right)$ at 30,60 DAS and at harvest, followed by FYM @ $5 \mathrm{t} \mathrm{ha}^{-1}+$ PSB. The residual effect of application of $90 \mathrm{~kg} \mathrm{P}_{2} \mathrm{O} 5 \mathrm{ha}^{-1}$ to soybean showed maximum available $\mathrm{N}\left(169.82,159.59\right.$ and $\left.147.03 \mathrm{~kg} \mathrm{ha}^{-1}\right), \mathrm{P}(11.00,10.38$ and $\left.9.66 \mathrm{~kg} \mathrm{ha}^{-1}\right)$ and $\mathrm{K}\left(711.46,693.21\right.$ and $\left.688.46 \mathrm{~kg} \mathrm{ha}^{-1}\right)$ at 30, 60 DAS and at harvest. Application of $100 \%$ RDF to wheat showed significant available N, P and K in soil over $50 \% \mathrm{RDF}$ and Control. The maximum uptake of $\mathrm{P} \mathrm{kg} \mathrm{ha}{ }^{-1}$, yield and quality parameters of wheat was recorded due to residual effect of VC @ $5 \mathrm{t} \mathrm{ha}^{-1}+\mathrm{PSB}, 90 \mathrm{~kg} \mathrm{P}_{2} \mathrm{O} 5 \mathrm{ha}^{-1}$ and application of $100 \%$ RDF.

\section{Introduction}

Among the cereals wheat is among the most primitive plants domesticated as food crops near about 8,000 years ago and since then it has been the major staple food for most parts of the world. In soybean-wheat cropping system, it is reported to apply RDF of $\mathrm{P}$ to soybean or 50 per cent to each crop rather than RDF to wheat. Meeting the requirement of soybean not only maximizes the production of soybean but also benefits wheat by the 
residual effect of $\mathrm{P}$ as a result of better biological $\mathrm{N}$ fixation under optimum $\mathrm{P}$. In soybean-wheat cropping, yields are increased significantly by the application of $\mathrm{P}$ to each crop. Phosphorus applied to soybean was more efficiently utilized by the succeeding crops compared to that applied to wheat in the system (Subba Rao et al., 1995). Sustaining crop production on long- term basis can be achieved through use of all possible sources of nutrients in a judicious way and ensuring their efficient and profitable use. Similarly, the use of biofertilizers in conjunction with chemical fertilizers as well as organic manures has prime importance because of increasing prices of fertilizers day by day. Therefore, it is necessary to reduce the cost of fertilizers by using biofertilizers for increasing crop yields (Nambiar and Ghosh, 1984).

\section{Materials and Methods}

The present investigation was conducted to study the residual effect of organics, Phosphorus levels and application of fertilizer levels on wheat under soybean-wheat cropping sequence in vertisols at college of agriculture, Parbhani (MS). The experiment was laid down in split plot design with 12 treatments in soybean and 36 treatments in succeeding wheat replicated thrice during 2010-11 and 2011-12. The experimental soil was clayey in texture, soil $\mathrm{pH}$ was found to be 8.17, organic carbon $3.80 \mathrm{~g} \mathrm{~kg}^{-1}$, and $\mathrm{CaCO}_{3}$ 7.18 per cent. Available $\mathrm{N}, \mathrm{P}_{2} \mathrm{O}_{5}$ and $\mathrm{K}_{2} \mathrm{O}$ were $131,5.84$ and $680 \mathrm{~kg} \mathrm{ha}^{-1}$, respectively. The experiment comprised of the treatments three sources of organic matter (0, FYM @ 5t $\mathrm{ha}^{-1}+$ PSB and Vermicompost (VC) @ 5 $\mathrm{ha}^{-1}$ + PSB ), four levels of P $(0,30,60$ and $90 \mathrm{~kg}$ $\mathrm{P} 2 \mathrm{O} 5 \mathrm{~kg}$ ha-1) and three fertilizer levels (0, $50 \% \mathrm{RDF}$ and $100 \% \mathrm{RDF})$ to wheat in soybean-wheat cropping sequence. Organic manures i.e. FYM and vermicompost were applied at the rate of $5 \mathrm{tha}^{-1}$ prior to 25 days of sowing. The seed treatment with PSB was done before sowing of the seed. Fertilizers were applied as per the treatment, through Urea, Diammonium phosphate and Muriate of potash prior to sowing of soybean. Similarly 50 per cent (50:25:25 NPK kg ha ${ }^{-1}$ ) and 100 per cent recommended dose of fertilizer (100:50:50 NPK $\mathrm{kg} \mathrm{ha}^{-1}$ ) for wheat was applied through Urea, Diammonium phosphate and Muriate of potash and half of the recommended dose of $\mathrm{N}$ for each treatment was applied as basal dose and remaining 50 per cent after one month of sowing of wheat. Soil samples were collected $(0-20 \mathrm{~cm})$ from each net plot at 30, 60 DAS and at harvest of wheat crops during both the years. The collected soil samples were thoroughly mixed brought to the laboratory, air dried and ground with porcelain mortar and pestle and passed through $2 \mathrm{~mm}$ sieve, for analyzing its available $\mathrm{N}, \mathrm{P}$ and $\mathrm{K}$. the available $\mathrm{N}$ was estimated by using alkaline permanganate method as suggested by Jackson (1973). Available P was determined by using $0.5 \mathrm{M}$ sodium bicarbonate as an extractant as outlined by Olsen et al., (1954), while available $\mathrm{K}$ was determined by using normal ammonium acetate as an extractant and measured on flame photometer (Jackson, 1973). The plant samples of wheat were uprooted and collected at 30,60 DAS and at harvest while grain sample was collected after harvest from each net plot. The phosphorus content in dry matter and grain was estimated colorimetrically by vanadomolybdo phosphoric acid yellow colour method. The yellow colour was measured on double beam UV-Spectrophotometer on respective wavelength as described by (Jackson, 1973). Uptake of $\mathrm{P}$ was computed considering the grain and straw yield and their respective concentration of phosphorus. The grain and straw yield of wheat crops was recorded separately from each net plot. The weight of weight of 1000 seed designated as test weight of wheat. The per cent nitrogen content from 
wheat grains was determined by Kjeldahl's method. The protein content was calculated by multiplying per cent nitrogen with the factor 5.70 for wheat (AOAC, 1975). The results obtained were statistically analyzed and appropriately interpreted as per the methods described in "Statistical methods for agricultural workers" by Panse and Sukhatme, (1985).

\section{Results and Discussion}

\section{Available N}

The data on available $\mathrm{N}$ (kg ha-1) in soil as influenced by residual organics and $\mathrm{P}$ levels (Table 1) showed non-significant increase in available $\mathrm{N}$ at 30 DAS and at harvest. whereas significant result in available $\mathrm{N} \mathrm{kg}$ ha-1in soil was observed at 60 DAS. Further the data indicated that available $\mathrm{N}$ significantly increased upto $169.82 \mathrm{~kg} \mathrm{ha}^{-1}$ due to residual effect of $90 \mathrm{~kg} \mathrm{P}_{2} \mathrm{O}_{5} \mathrm{ha}^{-1}$ at 30 DAS. The available $\mathrm{N}$ was further decreased significantly upto 159.59 and $147.03 \mathrm{~kg} \mathrm{ha}^{-1}$ at 60 DAS and at harvest respectively. Further reduction in the level of $P$, resulted in significant decline in available $\mathrm{N}$ and showed minimum value $139.28 \mathrm{~kg} \mathrm{ha}^{-1}$ in control at harvest. However, at subsequent growth stages of crops the maximum available $\mathrm{N}$ was recorded with residual effect of 60 and $90 \mathrm{~kg}$ $\mathrm{P}_{2} \mathrm{O}_{5} \mathrm{ha}^{-1}$ was found at par and found superior over $30 \mathrm{~kg} \mathrm{P}_{2} \mathrm{O}_{5} \mathrm{~kg} \mathrm{ha}^{-1}$ and control at harvest. The maximum available $\mathrm{N} 171.80 \mathrm{~kg}$ $\mathrm{ha}^{-1}$ at 30 DAS with application of 100 per cent RDF. While, it was decreased significantly upto $167.65 \mathrm{~kg} \mathrm{ha}^{-1}$ followed by 50 per cent RDF at 30 DAS. Similar pattern was followed at subsequent growth stages of crop. The interaction effect OXP, OXF, PXF and OXPXF was found non-significant in respect of available $\mathrm{N}$ at 30, 60 DAS and at harvest of the crop. The increase in available $\mathrm{N}$ due to incorporation of organic sources might be due to release of organic acids and mineralization of $\mathrm{N}$ during microbial decomposition, as a result of which increased the available $\mathrm{N}$ content in soil (Tanwar et al., 2004). Similarly the combined effect of different organic sources alone and in combination with fertilizer in soybean-wheat cropping system at IARI, New Delhi. He observed that available $\mathrm{N}$ increased slightly with 100 per cent NPK (211.2 $\mathrm{kg} \mathrm{ha}^{-1}$ ) and also combined use of 50 per cent or 100 per cent NPK with FYM and Poultry manure. Findings were also reported by Behera (2000).

\section{Available P}

The significant increase in available $\mathrm{P}$ upto $11.1 \mathrm{~kg} \mathrm{ha}^{-1}$ at $30 \mathrm{DAS}$ due to residual effect of VC @5 $\mathrm{t} \mathrm{ha}+$ PSB followed by significant decline upto $10.5 \mathrm{~kg} \mathrm{ha}^{-1}$ with an application of FYM + PSB (Table 1). Further, it is clear that there was considerable reduction in available $P$ to its minimum $9.8 \mathrm{~kg}$ ha-1 in control. Similar trend in available P was also recorded at subsequent growth stages of wheat crop. The available $P$ significantly increased upto $11.0 \mathrm{~kg} \mathrm{ha}^{-1}$ due to residual effect of $90 \mathrm{~kg} \mathrm{P}_{2} \mathrm{O}_{5} \mathrm{ha}^{-1}$ at 30 DAS. The available $\mathrm{P}$ was further decreased significantly upto $10.8 \mathrm{~kg} \mathrm{ha}^{-1}$ as the level of $\mathrm{P}$ was altered to $60 \mathrm{~kg} \mathrm{ha}^{-1}$. Further reduction in the level of $\mathrm{P}$, resulted in significant decline in available $\mathrm{P}$ and showed minimum value $9.8 \mathrm{~kg} \mathrm{ha}^{-1}$ in control. However, at subsequent growth stages of crops the maximum available $\mathrm{P}$ was recorded with residual effect of $60 \mathrm{~kg} \mathrm{P}_{2} \mathrm{O}_{5} \mathrm{ha}^{-1}$. Further, increase in $\mathrm{P}$ level showed slight decrease in available $P$ while, decrease in the level of $P$ significantly lowered the available $P$ and thereby minimum value was recorded in control. The maximum available $\mathrm{P} 13.3$ $\mathrm{kg} \mathrm{ha}^{-1}$ at 30 DAS with application of 100 per cent RDF. While, it was decreased significantly upto $11.5 \mathrm{~kg} \mathrm{ha}^{-1}$ as the fertilizer treatment was altered to 50 per cent RDF. 
Further, $\mathrm{P}$ availability reduced remarkably to its minimum upto $6.6 \mathrm{~kg} \mathrm{ha}^{-1}$ in treatment receiving no application of fertilizer. Similar pattern was followed at subsequent growth stages of crop. The interaction effect of OxP for available $\mathrm{P}$ was found significant at 30 DAS only. The interaction of $\mathrm{OxF}$ and $\mathrm{PxF}$ were found significant at all growth stages of wheat crop. However interaction effect of OxPxF was found significant at 60 DAS of wheat only. The increase in available $P$ due to incorporation of organic sources might be due to release of organic acids during microbial decomposition, helped in the solubility of native phosphates as a result of which increased the available $\mathrm{P}$ content in soil (Tanwar et al., 2004). Further, applied organic matter leads to formation of a coating on the clay complex and results in reduction in the phosphate fixing capacity of soil (Ramesh et al., 2009). The addition of FYM or vermicompost also resulted in the improvement of physico-chemical and biological characteristics of the soil and reduced the activity of $\mathrm{P}$ complexing agents to make more $\mathrm{P}$ available in soil Singh and Singh, (2006) and Ramesh et al., (2009). Further, improvement in available $\mathrm{P}$ status in soil due to application of organics in combination with 100 per cent RDF owing to mobilization of phosphorus from sub soil to upper region (Chitale et al., 2003). These results confirm the findings reported by Ingle et al., (2006) and Thakur and Sawarkar, (2009.

\section{Available K}

The data on available $\mathrm{K}$ (Table 1) in soil as influenced by residual organics and $\mathrm{P}$ levels showed significant increase in available $\mathrm{K}$ at all the crop growth stages. Among the organics the residual effect of VC @ $5 \mathrm{tha}^{-1}$ + PSB recorded maximum available K $710.13 \mathrm{~kg} \mathrm{ha}^{-1}$ at 30 DAS followed by FYM @ $5 \mathrm{t} \mathrm{ha}^{-1}+$ PSB (704.33 kg ha $\left.{ }^{-1}\right)$. Similar trend was observed in subsequent crop growth stages. The available $\mathrm{K}$ was significantly increased upto $711.46 \mathrm{~kg} \mathrm{ha}^{-1}$ due to residual effect of $90 \mathrm{~kg} \mathrm{P}_{2} \mathrm{O}_{5} \mathrm{ha}^{-1}$ at 30 DAS over rest of the levels of P. However the available $\mathrm{K}$ was decreased significantly and recorded minimum at harvest. The application of 100 per cent RDF to wheat showed maximum available $\mathrm{K}$ (720.90, 701.57 and 696.60 $\mathrm{kg} \mathrm{ha}^{-1}$ ) at 30, 60 DAS and at harvest and found superior over 50 per cent RDF and control. The interaction effect $\mathrm{OxP}, \mathrm{OxF}, \mathrm{PxF}$ and $\mathrm{OxPxF}$ was found non-significant in respect of available $K$ at 30, 60 DAS and at harvest of the crop. These results are in line with results reported by Thakur and Sawarkar (2009) that application of RDF+FYM @ 15t $\mathrm{ha}^{-1}$ to succeeding wheat after kharif soybean showed maximum availability of $\mathrm{N}(210.8 \mathrm{~kg}$ $\left.\mathrm{ha}^{-1}\right), \mathrm{P}\left(34.8 \mathrm{~kg} \mathrm{ha}^{-1}\right)$ and $\mathrm{K}\left(312.3 \mathrm{~kg} \mathrm{ha}^{-1}\right)$ followed by 50 per cent NPK applied alone at Jabalpur (M.P.) during 2006-07. Similar results were also found by Kotangale et al., (2009) at CRS, PDKV, Akola in sorghumwheat cropping sequence.

\section{Uptake of $P$}

The application of VC @ 5t ha ${ }^{-1}+$ PSB to soybean showed maximum $\mathrm{P}$ uptake of 4.4 and $8.3 \mathrm{~kg} \mathrm{ha}^{-1}$ in grain and straw, respectively (Table 2). Thus, total uptake also recorded maximum as $13.4 \mathrm{~kg} \mathrm{ha}^{-1}$. The $\mathrm{P}$ uptake was reduced considerably as the organic treatment was altered to FYM @ 5t $\mathrm{ha}^{-1}+$ PSB. Further, the P uptake was reduced drastically upto 3.3 and $6.7 \mathrm{~kg} \mathrm{ha}^{-1}$ in grain and straw, respectively, in control. The data further indicated that $\mathrm{P}$ uptake varied significantly in grain and straw due to residual effect of different $\mathrm{P}$ levels during both the years of experiment. The pooled data showed maximum $\mathrm{P}$ uptake in grain and straw 4.47 and $8.27 \mathrm{~kg} \mathrm{ha}^{-1}$, respectively due to residual effect of $90 \mathrm{Kg} \mathrm{P}_{2} \mathrm{O}_{5} \mathrm{ha}^{-1}$. The uptake of $\mathrm{P}$ in grain as well as straw was reduced 
significantly upto 4.30 and $8.11 \mathrm{~kg} \mathrm{ha}^{-1}$ as the level of $\mathrm{P}$ was reduced remarkably with every decrement in level of $\mathrm{P}$ thereby minimum $\mathrm{P}$ uptake of 3.25 and $6.64 \mathrm{~kg} \mathrm{ha}^{-1}$ in grain and straw, respectively. It is also evident from the data that the $\mathrm{P}$ uptake in wheat grain and straw was influenced significantly due to different levels of fertilizers during both the years. The data on pooled analysis showed that application of 100 per cent RDF to wheat resulted in highest $P$ uptake in grain and straw upto 4.5 and $8.6 \mathrm{~kg} \mathrm{ha}^{-1}$, respectively. The alteration in the level of fertilizer to 50 per cent RDF considerably reduced the $\mathrm{P}$ uptake and reached to minimum values with no application of fertilizers.

The increase in $\mathrm{P}$ uptake due to organic sources applied to preceding soybean crop may be due to improved nutrient availability in soil and thus benefited the succeeding wheat crop, secondly higher yield levels obtained with organic manures and $\mathrm{P}$ application also resulted in more uptake of $\mathrm{P}$ from soil as described by Singh and Singh, (2006). The higher $P$ content in grain and straw of wheat with increasing doses of $\mathrm{P}$ may be attributed to root proliferation by $\mathrm{P}$ resulting in better absorption and higher content of $\mathrm{P}$ in the crop thereby, showed higher uptake (Singh et al., 2004). These results are in conformity with the findings reported by Hile et al., (2009).

\section{Grain and straw yield}

The data indicated (Table 2) significant residual effect of organics on grain yield of wheat. The application of VC@ $5 \mathrm{t} \mathrm{ha}^{-1}+$ PSB resulted in maximum grain and straw yield (28.4 q ha $\mathrm{q}^{-1}$ and $41.73 \mathrm{~kg} \mathrm{q} \mathrm{ha}^{-1}$ ). The grain and straw yield was reduced considerably upto 26.4 and $38.83 \mathrm{q} \mathrm{ha}^{-1}$ with residual effect of FYM @ 5t ha ${ }^{-1}+$ PSB. Further, it is noted that the grain and straw yield of wheat reduced drastically upto 24.1 and $35.23 \mathrm{q} \mathrm{ha}^{-1}$ in control and was significantly lower than recorded due to residual effect of organics. The higher grain and straw yield of 28.1 and $40.89 \mathrm{q} \mathrm{ha}^{-1}$ was recorded due to residual effect of $90 \mathrm{~kg} \mathrm{P}_{2} \mathrm{O}_{5} \mathrm{ha}^{-1}$. The grain and straw yield was reduced slightly upto 27.7 and $39.96 \mathrm{q} \mathrm{ha}^{-1}$ as the $\mathrm{P}$ level was altered to 60 $\mathrm{kg} \mathrm{P}_{2} \mathrm{O}_{5} \mathrm{ha}^{-1}$. Further, the grain and straw yield was found to decrease significantly upto 25.4 and $24.1 \mathrm{q} \mathrm{ha}^{-1}, 37.62$ and $35.83 \mathrm{q} \mathrm{ha}^{-1}$ as the level of $\mathrm{P}$ was reduced to 30 and $0 \mathrm{~kg}$ $\mathrm{P}_{2} \mathrm{O}_{5} \mathrm{ha}^{-1}$, respectively. The application of fertilizer showed maximum grain and straw yield of 29.4 and $42.34 \mathrm{q} \mathrm{ha}^{-1}$ recorded with 100 per cent RDF, decreased considerably upto 27.5 and $39.80 \mathrm{q} \mathrm{ha}^{-1}$ with an addition of 50 per cent RDF. The grain and straw yield was further reduced drastically upto 22.0 and $33.66 \mathrm{q} \mathrm{ha}^{-1}$ with no application of fertilizer. The interaction of residual organic sources $X$ $P$ levels influenced the grain yield of wheat. It is clearly seen that, maximum grain and straw yield of wheat was recorded due to residual

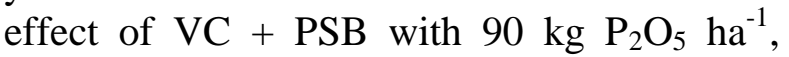
followed by slight reduction in yield due to residual effect of FYM + PSB with $60 \mathrm{~kg}$ $\mathrm{P}_{2} \mathrm{O}_{5} \mathrm{ha}^{-1}$. The interaction of residual organic sources $\mathrm{X}$ direct application of fertilizer on grain and straw yield of wheat. The interaction of VC @ $5 \mathrm{t} \mathrm{ha}^{-1}+$ PSB with 100 per cent RDF produced maximum grain and straw yield followed by FYM @ $5 \mathrm{t} \mathrm{ha}^{-1}+$ PSB + PSB with 50 per cent RDF. The maximum grain and straw yield of wheat due to the interaction of 100 per cent with 90 as well as $60 \mathrm{~kg} \mathrm{P}_{2} \mathrm{O}_{5} \mathrm{ha}^{-1}$. The interaction of application of 100 per cent RDF x $90 \mathrm{~kg} \mathrm{P}_{2} \mathrm{O}_{5}$ $\mathrm{ha}^{-1} \mathrm{x}$ VC@ $@ \mathrm{t} \mathrm{ha}^{-1}+$ PSB showed highest grain and yield of $33.8 \mathrm{q} \mathrm{ha}^{-1}$. Similar yields are also recorded due to the interaction of 100 per cent RDF x 60 kg $\mathrm{P}_{2} \mathrm{O}_{5} \mathrm{ha}^{-1}$ x VC @ 5t $\mathrm{ha}^{-1}+\mathrm{PSB}$ and 50 per cent RDF X $90 \mathrm{~kg} \mathrm{P}_{2} \mathrm{O}_{5}$ $\mathrm{ha}^{-1}$ x VC@ $@ \mathrm{t} \mathrm{ha}^{-1}+$ PSB. 
Table.1 Available N, P and $\mathrm{K}\left(\mathrm{kg} \mathrm{ha}^{-1}\right)$ in soil as influenced by residual organics, $\mathrm{P}$ levels and direct application of fertilizer to wheat crop

\begin{tabular}{|c|c|c|c|c|c|c|c|c|c|}
\hline \multirow[t]{2}{*}{ Treatment } & \multicolumn{3}{|c|}{ Available N (kg ha $\left.{ }^{-1}\right)$} & \multicolumn{3}{|c|}{ Available $\mathbf{P}\left(\mathrm{kg} \mathrm{ha}^{-1}\right)$} & \multicolumn{3}{|c|}{ Available K (kg ha $\left.{ }^{-1}\right)$} \\
\hline & $\begin{array}{c}30 \\
\text { DAS }\end{array}$ & $\begin{array}{c}60 \\
\text { DAS }\end{array}$ & $\begin{array}{c}\mathrm{At} \\
\text { harvest }\end{array}$ & $\begin{array}{c}30 \\
\text { DAS }\end{array}$ & $\begin{array}{c}60 \\
\text { DAS }\end{array}$ & $\begin{array}{c}\text { At } \\
\text { harvest }\end{array}$ & $\begin{array}{c}30 \\
\text { DAS }\end{array}$ & $\begin{array}{c}60 \\
\text { DAS }\end{array}$ & $\begin{array}{c}\text { At } \\
\text { harvest }\end{array}$ \\
\hline \multicolumn{10}{|l|}{ Organic manure } \\
\hline $\mathrm{O}_{0}:$ Control & 161.06 & 150.29 & 139.33 & 9.89 & 9.35 & 8.71 & 692.23 & 675.67 & 670.71 \\
\hline$O_{1}:$ FYM $5 \mathrm{t} \mathrm{ha}^{-1}+$ PSB & 167.76 & 157.23 & 144.44 & 10.55 & 9.96 & 9.30 & 704.33 & 684.49 & 679.53 \\
\hline $\begin{array}{l}\mathrm{O}_{2}: \text { Vermicompost } 5 \mathrm{t} \\
\text { ha }^{-1}+\mathrm{PSB}\end{array}$ & 170.29 & 160.82 & 146.25 & 11.16 & 10.43 & 10.30 & 710.13 & 701.18 & 686.76 \\
\hline S.E. \pm & 2.63 & 1.05 & 4.21 & 0.030 & 0.07 & 0.02 & 0.62 & 1.02 & 1.12 \\
\hline C.D. at $\mathbf{5 \%}$ & NS & 4.08 & NS & 0.09 & 0.21 & 0.06 & 3.79 & 6.20 & 6.62 \\
\hline \multicolumn{10}{|l|}{$P$ levels $\left(\mathrm{P}_{2} \mathrm{O}_{5} \mathrm{~kg} \mathrm{ha}^{-1}\right)$} \\
\hline $\mathbf{P}_{0}: 0$ & 160.97 & 151.04 & 139.28 & 9.89 & 9.07 & 8.58 & 690.03 & 672.46 & 667.50 \\
\hline $\mathbf{P}_{1}: \mathbf{3 0}$ & 161.18 & 156.43 & 142.16 & 10.37 & 9.82 & 9.17 & 699.67 & 680.27 & 675.30 \\
\hline$P_{2}: 60$ & 168.50 & 157.40 & 144.88 & 10.87 & 10.39 & 9.69 & 707.78 & 689.90 & 684.93 \\
\hline$P_{3}: 90$ & 169.82 & 159.59 & 147.03 & 11.00 & 10.38 & 9.66 & 711.46 & 693.21 & 688.46 \\
\hline S.E. \pm & 1.43 & 0.90 & 1.38 & 0.04 & 0.08 & 0.06 & 0.51 & 0.46 & 0.51 \\
\hline C.D. at $5 \%$ & 4.59 & 2.89 & 4.40 & 0.12 & 0.26 & 0.20 & 1.63 & 1.49 & 1.56 \\
\hline \multicolumn{10}{|l|}{ Fertilizer levels } \\
\hline$F_{0}$ : No application & 159.65 & 148.40 & 137.57 & 6.68 & 6.26 & 5.74 & 679.91 & 661.97 & 657.01 \\
\hline $\begin{array}{l}F_{1}: 50: 25: 25 \text { NPK kg } \\
\text { ha }^{-1}\end{array}$ & 167.65 & 158.41 & 144.17 & 11.57 & 11.05 & 10.38 & 705.89 & 688.34 & 683.38 \\
\hline $\begin{array}{l}F_{2}: 100: 50: 50 \text { NPK kg } \\
\text { ha }^{-1}\end{array}$ & 171.80 & 161.52 & 148.27 & 13.34 & 12.43 & 11.71 & 720.90 & 701.57 & 696.60 \\
\hline SE \pm & 0.75 & 0.67 & 0.621 & 0.04 & 0.060 & 0.07 & 0.37 & 0.53 & 0.60 \\
\hline CD at $5 \%$ & 2.08 & 1.36 & 1.72 & 0.13 & 0.18 & 0.21 & 1.02 & 1.48 & 1.81 \\
\hline \multicolumn{10}{|l|}{ Interactions } \\
\hline \multicolumn{10}{|l|}{$\mathbf{O} \times \mathbf{P}$} \\
\hline SE \pm & 2.48 & 1.56 & 2.39 & 0.075 & 0.14 & 0.11 & 0.88 & 0.81 & 0.84 \\
\hline CD at $5 \%$ & NS & NS & NS & 0.20 & NS & NS & NS & NS & NS \\
\hline \multicolumn{10}{|l|}{$\mathbf{O} \times \mathbf{F}$} \\
\hline S.E. \pm & 1.30 & 1.16 & 1.07 & 0.083 & 0.10 & 0.11 & 0.64 & 0.92 & 0.96 \\
\hline C.D. at $5 \%$ & NS & NS & NS & 0.23 & 0.30 & 0.31 & NS & NS & NS \\
\hline \multicolumn{10}{|l|}{$\mathbf{P} \times \mathbf{F}$} \\
\hline S.E. \pm & 1.50 & 1.35 & 1.24 & 0.096 & 0.12 & 0.13 & 0.74 & 1.07 & 1.12 \\
\hline C.D. at $5 \%$ & NS & NS & NS & 0.26 & 0.34 & 0.36 & NS & NS & NS \\
\hline \multicolumn{10}{|l|}{ O x P xF } \\
\hline S.E. \pm & 2.60 & 2.33 & 2.15 & 0.16 & 0.216 & 0.22 & 1.28 & 1.85 & 1.94 \\
\hline C.D. at $5 \%$ & NS & NS & NS & NS & 0.598 & NS & NS & NS & NS \\
\hline
\end{tabular}


Table.2 $\mathrm{P}$ uptake $\left(\mathrm{kg} \mathrm{ha}^{-1}\right)$, yield and quality parameters as influenced by residual organics, $\mathrm{P}$ levels and direct application of fertilizer to wheat crop

\begin{tabular}{|c|c|c|c|c|c|c|c|c|}
\hline \multirow[t]{2}{*}{ Treatment } & \multicolumn{3}{|c|}{ P Uptake $\left(k^{\prime g ~ h a}{ }^{-1}\right)$} & \multicolumn{3}{|c|}{ Yield $\left(q\right.$ ha $\left.^{-1}\right)$} & \multicolumn{2}{|c|}{ Quality Parameters } \\
\hline & Grain & Straw & Total & Grain & Straw & Total & $\begin{array}{c}\text { Test Weight } \\
\text { (g) }\end{array}$ & $\begin{array}{l}\text { Protein } \\
(\%)\end{array}$ \\
\hline \multicolumn{9}{|l|}{ Organic manure } \\
\hline $\mathrm{O}_{0}:$ Control & 3.33 & 6.74 & 10.07 & 24.16 & 35.23 & 59.39 & 35.58 & 10.64 \\
\hline $\mathrm{O}_{1}:$ FYM $5 \mathrm{t} \mathrm{ha}^{-1}+$ PSB & 3.95 & 7.57 & 11.52 & 26.41 & 38.83 & 65.25 & 36.34 & 10.95 \\
\hline $\begin{array}{l}\mathrm{O}_{2}: \text { Vermicompost } 5 \mathrm{t} \\
\mathrm{ha}^{-1}+\mathrm{PSB}\end{array}$ & 4.47 & 8.32 & 13.40 & 28.44 & 41.73 & 70.18 & 36.60 & 11.28 \\
\hline S.E. \pm & 0.076 & 0.24 & 0.34 & 0.65 & 1.23 & 0.61 & 0.074 & 0.023 \\
\hline C.D. at $5 \%$ & 0.23 & 0.73 & 1.08 & 1.95 & NS & 1.83 & 0.23 & 0.07 \\
\hline \multicolumn{9}{|l|}{$\mathrm{P}$ levels $\left(\mathrm{P}_{2} \mathrm{O}_{5} \mathrm{~kg} \mathrm{ha}^{-1}\right)$} \\
\hline $\mathbf{P}_{0}: 0$ & 3.25 & 6.64 & 9.90 & 24.11 & 35.83 & 59.95 & 35.85 & 10.61 \\
\hline $\mathbf{P}_{1}: 30$ & 3.64 & 7.15 & 10.79 & 25.41 & 37.62 & 63.04 & 36.00 & 10.88 \\
\hline$P_{2}: 60$ & 4.30 & 8.11 & 12.41 & 28.10 & 39.96 & 67.67 & 36.34 & 11.14 \\
\hline$P_{3}: 90$ & 4.47 & 8.27 & 12.74 & 0.197 & 40.98 & 69.11 & 36.50 & 11.19 \\
\hline S.E. \pm & 0.040 & 0.024 & 0.05 & 0.630 & 0.170 & 0.18 & 0.053 & 0.015 \\
\hline C.D. at $5 \%$ & 0.128 & 0.07 & 0.15 & 1.89 & 0.54 & 0.58 & 0.14 & 0.04 \\
\hline \multicolumn{9}{|l|}{ Fertilizer levels } \\
\hline$F_{0}$ : No application & 3.05 & 6.07 & 9.13 & 22.02 & 33.66 & 55.68 & 35.62 & 10.10 \\
\hline $\begin{array}{l}F_{1}: 50: 25: 25 \text { NPK kg } \\
\text { ha- }^{-1}\end{array}$ & 4.12 & 7.95 & 12.07 & 27.58 & 39.80 & 67.39 & 36.28 & 11.26 \\
\hline $\begin{array}{l}F_{2}: 100: 50: 50 \text { NPK kg } \\
h^{-1}\end{array}$ & 4.57 & 8.60 & 13.17 & 29.41 & 42.34 & 71.75 & 36.63 & 11.51 \\
\hline SE \pm & 0.017 & 0.038 & 0.06 & 0.12 & 0.210 & 0.21 & 0.032 & 0.098 \\
\hline CD at $5 \%$ & 0.049 & 0.107 & 0.18 & 0.32 & 0.58 & 0.60 & 0.88 & 0.291 \\
\hline \multicolumn{9}{|l|}{ Interactions } \\
\hline \multicolumn{9}{|l|}{$\mathbf{O} \times \mathbf{P}$} \\
\hline SE \pm & 0.069 & 0.14 & 0.69 & 0.34 & 0.29 & 0.31 & 0.092 & 0.013 \\
\hline CD at $5 \%$ & NS & NS & NS & 1.09 & NS & 1.01 & 0.25 & 0.041 \\
\hline \multicolumn{9}{|l|}{$\mathbf{O} \times \mathbf{F}$} \\
\hline S.E. \pm & 0.030 & 0.067 & 0.61 & 0.20 & 0.36 & 0.37 & 0.055 & 0.017 \\
\hline C.D. at $5 \%$ & 0.084 & 0.18 & NS & 0.56 & 1.00 & 1.04 & NS & 0.047 \\
\hline \multicolumn{9}{|l|}{$\mathbf{P} \times \mathbf{F}$} \\
\hline S.E. \pm & 0.035 & 0.077 & 0.71 & 0.23 & 0.42 & 0.43 & 0.064 & 0.019 \\
\hline C.D. at $5 \%$ & 0.098 & 0.214 & NS & 0.65 & NS & 1.20 & 0.17 & 0.054 \\
\hline \multicolumn{9}{|l|}{ O x P xF } \\
\hline S.E. \pm & 0.061 & 0.13 & 1.23 & 0.40 & 0.72 & 0.75 & 0.11 & 0.034 \\
\hline C.D. at $5 \%$ & NS & NS & NS & 1.110 & NS & NS & NS & 0.094 \\
\hline
\end{tabular}


The increase in grain and straw yield of wheat due to residual effect of $\mathrm{P}$ may be attributed to the fact that the $\mathrm{P}$ is to be directly related to the reproductive growth of the crop and attributed complex phenomenon of phosphorus utilization in plant metabolism. It also helps in efficient absorption and utilization of other nutrients which ultimately increased the grain and straw yield (Singh and Rai, 2002). The increase in the grain and straw yield owing to increase in level of direct application of fertilizer may be because of adequate quantities and balanced proportion of plant nutrients applied to the crop during growth period as described by Thakur et al., (1999). Similar results are also recorded by Mankotia et al., (2008) and Ghanshyam et al., (2010).

\section{Test weight}

The residual effect of VC @ $5 \mathrm{tha}^{-1}+\mathrm{PSB}$ and $\mathrm{P} 90 \mathrm{~kg} \mathrm{P}_{2} \mathrm{O}_{5} \mathrm{ha}^{-1}$ recorded maximum test weight of 36.60 and $36.50 \mathrm{~g}$ over residual effect of FYM @5t ha ${ }^{-1}+$ PSB and rest of the levels of P. The higher test weight of wheat grain $36.63 \mathrm{~g}$ was recorded with an application of 100 per cent RDF. The test weight was slightly reduced $36.5 \mathrm{~g}$ as the level of fertilizer reduced to 50 per cent RDF. However, their was a drastic reduction in test weight of wheat grain upto $35.3 \mathrm{~g}$ with no application of fertilizer. The increase in test weight of wheat due to addition of FYM/vermicompost added with PSB created favourable condition to $\mathrm{P}$ availability to the plants. The higher nutrient uptake and its translocation had conducive effect on photosynthesis and accumulation and translocation of photosynthates to reproductive parts. Besides this, the microorganisms also produce growth promoting substances like IAA and GA which enhanced the plant growth. At the same time phosphorus might have played crucial role in proper development and maturity of seed which led to higher test weight (Singh and Rai, 2002). The increase in test weight due to residual effect of $\mathrm{P}$ may be owing to the fact that phosphorus fertilized plots might have attained their full capacity of sink size and manifested in to bold and heavier grains of wheat (Singh and Rai, 2002). The increase in test weight due to residual effect of $\mathrm{P}$ was also recorded by Behera et al., (2007) and Sammauria and Yadav et al., (2008).

\section{Protein content}

The data (Table 2) showed highest protein content 11.2 per cent due to residual effect of VC @ 5t ha ${ }^{-1}$ PSB, followed by significant decrease upto 10.9 per cent with residual effect of FYM + PSB. Further, it was reached to minimum upto 10.6 per cent in control. The maximum protein content of 11.19 per cent due to residual effect of $90 \mathrm{~kg} \mathrm{P}_{2} \mathrm{O}_{5} \mathrm{ha}^{-1}$, followed by significant decrease upto 11.14 per cent with residual effect of $60 \mathrm{~kg} \mathrm{P}_{2} \mathrm{O}_{5}$ $\mathrm{ha}^{-1}$. The protein content was further reduced significantly upto 10.88 per cent as the level of $\mathrm{P}$ altered to $30 \mathrm{~kg} \mathrm{P} \mathrm{P}_{5} \mathrm{O}^{-1}$ and then reached to minimum protein content of 10.61 per cent with $0 \mathrm{~kg} \mathrm{P}_{2} \mathrm{O}_{5} \mathrm{ha}^{-1}$. The data indicated highest protein content 11.5 per cent due to application of 100 per cent RDF in wheat grain which declined slightly upto 11.2 per cent as the level of fertilizer altered to 50 per cent RDF. The interaction of organics $x P$ levels, organics $\mathrm{x}$ fertilizers and $\mathrm{P}$ levels $\mathrm{x}$ fertilizer levels significantly affected the protein content in wheat grain. The increase in protein content in wheat with addition of organic sources might be due to modified soil environment along with improvement in physical properties of soil due to slow microbial decomposition of humus results in gradual increase of nutrients during succeeding wheat crop (Tanwar and Shaktawat, 2003). Thus, increased P availability resulted in better root formation and proliferation ultimately resulted in higher 
absorption and $\mathrm{N}$ content of seed (Sharma and Vyas, 2002). The increase in protein content due to direct application of fertilizers to wheat may be due to increased $P$ availability through fertilization. This increase in available $\mathrm{P}$ enhanced the $\mathrm{N}$ accumulation in seed which ultimately resulted in high content of protein. The increase in protein content in seed with increasing level of $\mathrm{P}$ was also recorded by Dhama and Sinha, (1985).

\section{References}

A.O.A.C. (1975). Official Methods of Analysis, Ed. 12, Association of Official Analytical Chemist, Washington, D.C.

Behera, U.K. (2000). Integrated nutrient management for sustaining productivity, quality and profitability of wheatsoybean cropping system. Indian Farming. Dec. pp 32-38.

Behera, U.K., S. Pradhan and A.R. Sharma (2007). Effect of integrated nutrient management practices on productivity of durum wheat (Triticum durum) in the Vertisols of central India, Indian $J$. Agric. Sci. 77(10): 635-638.

Chitale, S.R., R.K. Bajpal, S.K. Upadhyay and B.S. Joshi (2003). Influence of cereals-legume, legume-cereal and cereal-cereal sequences on productivity and soil fertility status. Madras Agric. J., 90 (10-12): 733-736.

Dhama, A.K. and M.N. Sinha (1985). Residual and cumulative effects of kharif grain legumes and $\mathrm{P}$ applied to the succeeding wheat : A study on $\mathrm{N}, \mathrm{P}$ concentration and their uptake, Indian $J$. Agron., 30 (4): 422-425.

Ghanshyam, Rakesh kumar and R.K. Jat (2010). Productivity and soil fertility as effected by organic manures and inorganic fertilizers in greengram (Vigna radiata)-wheat (Triticum aestivum) system. Indian J. Agron., 55
(1): 16-21.

Hile, R.B., S.M. Todmal and A.G. Wani (2009). Effect of N, P and $\mathrm{K}$ on productivity and nutrient uptake in pearl millet-wheat cropping sequence, $J$. Maharashtra agric. Univ., 34 (3): 360361.

Ingle, S.N., V.D. Guldekar, V.O. Jadhav and K.N. Lokhande (2006). Effect of different levels of major nutrients on yield of wheat and fertility status of Vertisols, P.K.V. J., 30 (2): 240-242.

Jackson, M.L. (1973). Soil Chemical Analysis. Prentice Hall of India Private Ltd. New Delhi. Pp. 498.

Kotangle, V.S., P.R. Bharambe, J.R. Katore and H.N. Ravanlar (2009a). Influence of organic and inorganic fertilizers on fertility status of soil under sorghumwheat cropping sequence in Vertisols. $J$. Soils and Crops, 19 (2): 347-350.

Mankotia, B.S., J. Shekhar, R.C. Thakur and S.C. Negi (2008). Effect of organic and in-organic sources of nutrients on rice (Oryza sativa) wheat (Triticum aestivum) cropping sequence, Indian $J$. Agron. 53 (1): 32-36.

Nambiar, K.K.M. and A.B. Ghosh (1984). In LTFE Res. Bull. Indian Agric. Res. Inst. New Delhi. pp 101.

Olsen, S.R., Cole, C.V., Watanabe, F.S. and Dean, E. (1954). Estimation of available phosphorus by extraction with $\mathrm{NaHCO}_{3}$. Cir. 939, U.S., Dept. Agric. pp 19-20.

Panse, U.G. and Sukhatme, P.V. (1985). Statistical Methods for Agricultural Workers, I.C.A.R. Pub., New Delhi. pp. 600-603.

Ramesh, P., N.R. Panwar, A.B. Singh and S. Ramana (2009). Production potential, nutrient uptake, soil fertility and economics of soybean (Glycine max)based cropping systems under organic, chemical and integrated nutrient management practices, Indian J .Agron. 
54 (3): 278-283.

Sammauria, R. and R.S. Yadav (2008). Effect of phosphorus and zinc application on growth and yield of fenugreek (Trigonella-foenum-graecum) and their residual effect on succeeding pearl millet (Pennisetum glaucum) under irrigated condition of north west Rajasthan, Indian J. Agric. Sci., 78 (1): 61-64.

Sharma, S.C. and A.K. Vyas (2002). Influence of Phosphorus Nutrition and FYM on Quality Parameters of Soyabean and Succeeding Wheat, Ann.Agric. Res. New Series 23 (1): 141145

Singh Tejpal and R.K. Rai (2002). Effect of phosphorus levels and phosphate solubilizing micro-organisms on yield and yield attributes of wheat (Triticum aestivum). Indian J. Agron. 47 (2): 216220.

Singh, Adesh and N.P. Singh (2006). Direct and residual effect of organic and inorganic sources of nutrients under urdbean (Vigna mungo)-wheat (Triticum aestivum) cropping sequence in foot hills of Uttaranchal, Indian $J$. Agron. 51 (2): 97-99.

Singh, Ravindra and S.K. Agrawal (2004). Effect of organic manuring and nitrogen fertilization on productivity, nutrient use efficiency and economics of wheat (Triticum aestivum) Indian J. Agron., 49
(1): 49-52.

Subba Rao, A.K. Sammi Reddy and P.N. Takkar (1995). Phosphorus management- A key to boost productivity of soybean-wheat cropping system on swell-shrink soils. Fert.News. 40 (12): 87-95.

Tanwar, S.P.S. and M.S. Shaktawat (2003). Influence of Phosphorus sources, levels and solubilizers on yield, quality and nutrient uptake of soybean (Glysine max L.)- wheat (Triticum aestivum) cropping system in sourthern Rajasthan. Indian J. Agric. Sci. 73 (1): 3-7

Tanwar, S.P.S., M.S.Shaktawat and A.K. Vyas, (2004). Balance sheet of nitrogen and phosphorus as influenced by integrated phosphorus management in soybean-wheat cropping system in southern Rajasthan, Ann. Agric. Res. New series 25 (1): 60-64.

Thakur Rishikesh and S.D. Sawarkar (2009). Influence of long term continuous application of nutrients and spatial distribution of sulphur on soybeanwheat cropping sequence, $J$ Soils and Crops, 19 (2): 225-228.

Thakur, S.S., I.B. Pande and S.S. Mishra (1999). Effect of organic manures, fertilizer level and seed rate on yield and quality of late-sown wheat (Triticum aestivum). Indian J. Agron. 44 (4): 754-759.

\section{How to cite this article:}

Waghmare, M. S., P. G. Chavan and Rathod, P. K. 2020. Residual Effect of Organics, Phosphorus Levels and Application of Fertilizer Levels on Wheat in Soybean-Wheat Cropping Sequence in Vertisols. Int.J.Curr.Microbiol.App.Sci. 9(06): 666-675.

doi: https://doi.org/10.20546/ijcmas.2020.906.085 